BMC JOURNAL OF SCIENTIFIC RESEARCH
A Multidisciplinary Research Journal
ISSN: 2594-3421

\title{
To study the macro habitat of fishes of Narayani river
}

\author{
Saroj Prasad Sah* \\ sarojshah391@gmail.com
}

\begin{abstract}
33 species of fishes are found in Narayani river. Most of the fishes are migratory. A large number of species are reported in mid water column. A few fish species are crevice of rocks and stones. Fishes are arranged in stratification pattern in Narayani River. Maximum fish species are encountered in Mid water column. Minimum fish species are reported in crevices of rocks and bottom of stream.
\end{abstract}

Keywords: Narayani river, genera, net, macro habitat, fish.

\section{Introduction:}

Narayani or seven Gandak system is one of the mightiest and at the same time, it is a typical tropical river of Nepal which is much changed due to human influences. The total length of the Narayani river is about $332 \mathrm{~km}$ and discharge 52,930 cusecs (Shrestha, 2001).

The Narayani is the final collector of seven extremely complex drainage system of trans Himalaya. The different sections are of several distinct types varying morphology of their beds as well as physico-chemical of their water, all these qualities being determined by the geographical history of the area.

The river Narayani system plays a vital role in development of fisheries of Nepal. In constitutes, one of main natural resources of fish seed(spawn) much needed throughout the country for the fast growing fishes has not been fully exposed.

The feeder streams of Narayani show varied ionic composition but the main Narayani river display a more or less constant composition through season. Water chemistry of river Narayani at Narayangarh are sodium(Na) $2.4 \mathrm{mg} / \mathrm{lit}$, potassium(K)2.0 mg/lit, bicarbonates $(\mathrm{HCO} 3) 118.0$ $\mathrm{mg} / \mathrm{lit}$, sulphate(SO4),14.0mg/lit, chlorides(Cl) $1.6 \mathrm{mg} / \mathrm{lit}$, hardness(CaCO3),96.20 mg/lit,PH7.5 ,temperature $28.33^{\circ} \mathrm{C}$ (shrestha 1990)

Fishes of Narayani river are well adapted to specific biotopes. Fishes which partially burry themselves in sandy bottoms such as stone loach (Noemacheilus beavani), cat fish(Heteropneustes fossilis), snake head( Channa striatus) fishes that school mid water column for predations includes barilius bendelisis, Acrossocheilus hexagonolepis, Puntius ticto. Fish that live permanently or temporarily underneath the rock and gravels,such as Pseudecheneis sulcatus, Glyptothorax cavia etc.(Sah,1995).There are 28 species reported in Trishuli river(Masuda and Karki(1980).The present paper deals with the macro habitat of fishes of Narayani river.

\footnotetext{
* Mr. Sah is Lecturer in Zoology at Birendra Multiple Campus
} 


\section{Materials and methods:}

For regular study fishes collection were carried out from Devghat to Nagarban(Narayangarh). Fishes were collected in different seasons form Devghat to Nagarban areas. In each visit different gears and appliances used by the fisherman and catch composition were recorded and ecological observations were made.

The live specimens of fishes were collected with the help of local fishermen. Fishes were collected from selected sites with the help of gill nets, cast nets and scoop nets and incised fish samples were preserved in $8 \%$ formalin.

Fishes were identified with the help of book" Fishes of Nepal (Shrestha, 1981), Icthyology of Nepal (Shrestha, 2008) fishes of U.P and Bihar (Srivastava,1980) and different websites. Fish experts of Agriculture Campus Rampur also helped in the identification of fishes. The primary data was adopted by concerning of local fishermen and questionire. The secondary data was established by concerning different websites. The size, weight, local name and zoological name of fishes were noted down in the field with the help of local people.

Results: There is clear stratification in Narayani river. Different species of fishes are dwell in eleven water levels. Fishes of running water of Narayani river are adapted to special macro habitat which are described as follows:

1. Partially buried sandy bottoms Fishes: stone loach (Noemacheilus beavani), snake head (Channa striatus)

2. Sheltered water of crevices of rock and stone: freshwater eel Anguilla bengalensis

3. Mid-water column fishes: Barilius bendelesis, Acrossocheilus hexagondepis, Puntius sarana, P. ticto, Pseudochenis sulcatus

4. Sub surface water fishes: Tor tor, Acrossocheilus hexagonolepis

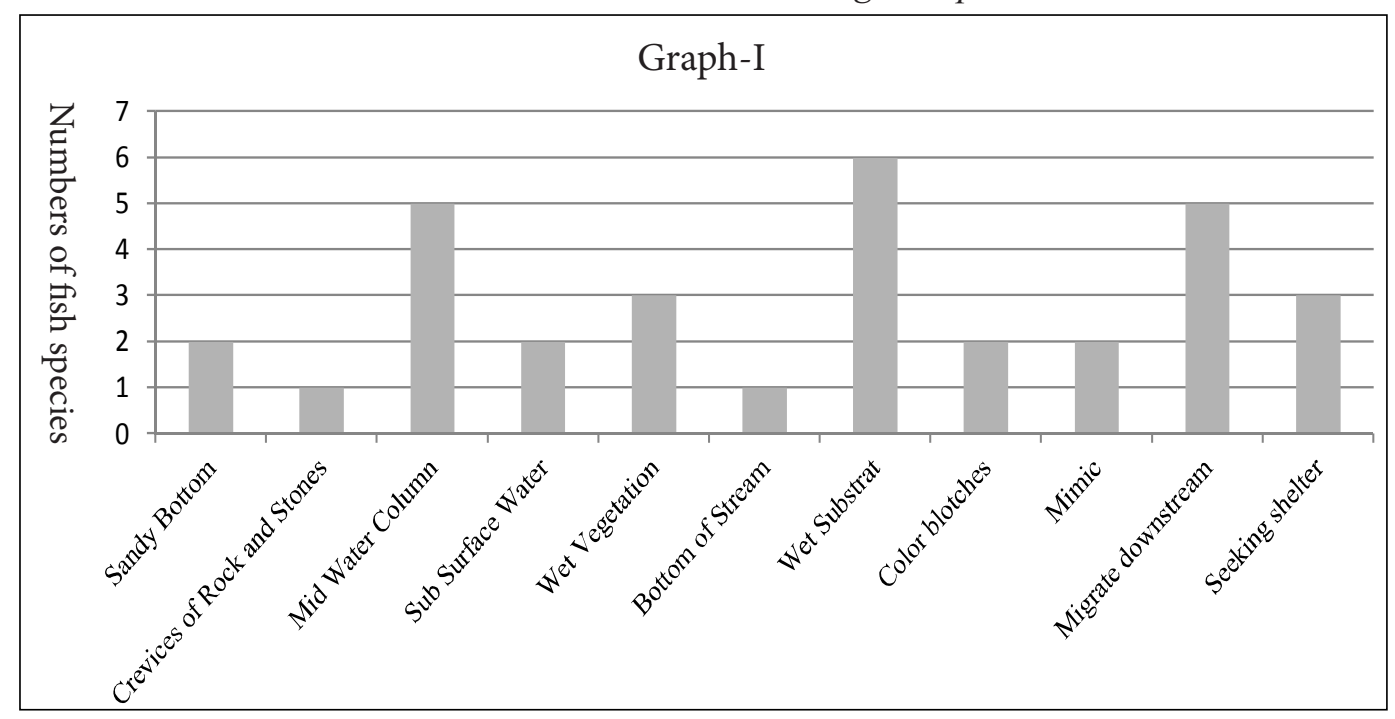

Macrohabitat of fishes 
5. Wet vegetation fishes: Cat fish(Heteropneustes fossilis), Murrel(Channa striatus), Amphipnous cuchia

6. Bottom dwelling fishes: Glyptothorax telchitta

7. Migratory fishes.: Schizothorax richardsoni, Garrra mullya, Tot tor T.putitora, Accrossocheilus hexagonolepis, Pseudeutropius murius

8. Colour blotching fishes: Puntius sarana, P.ticto

9. Mimicry fishes: Mud eel(Amphipnous cuchia) and fresh water eel (Anguilla bengalensis

10. Down stream to up stream migratory fishes:Tor tor, Tor putitora, Schizothorax progastus, S. richardsoni, Acrossocheilus hexagonolepis

11. Semi-submerged trees and bushes at high water fishes: Garra gotyla G. nandeli, Labeo dero

\section{Discussion}

Total 33 fish species are reported in studied area. Maximum number of fish species are migratory which are six genera. Five genera of species are reported from the mid water column and downstream migratory minimum species of fishes are reported from sandy bottom region of river, crevice of rocks and stones and stream floor. The moderate fish genera are found in sub surface and mimic of log and shelter in trees and bushes. They are two each respectively.

\section{References}

Masuda, K and Karki, K.B (1980): Fish and fisheries of Trishuli river .A report on the survey of the Trishuli river conducted in 1979. Fisheries Devsection, HMG. Nepal.

Sah, S.P (1995): Study on the biodiversity of the fishes with reference to the ecological changes.

Shrestha.J (1981): Fishesof Nepal, CDC, Tribhuwan University, Kathmandu.

Shrestha, T.K (1990): Resource ecology of Himalayan waters, Curriculum development Centre, T.U. Kathmandu

Shrestha, J. 2001. Taxonomic Revision of Fishes of Nepal. In: Environment and Agriculture: Biodiversity, Agriculture and Pollution in South Asia. (ed. P.K. Jha, S.K. Baral, CS.B. Karmacharya, H.D. Lekhak, P. Lacoul and C.B. Baniya), pp171-180. Ecological Society (ECOS), Kathmandu, Nepal. Shrestha T.K (2008): Ichthyology of Nepal, Himalayan ecosphere. 